
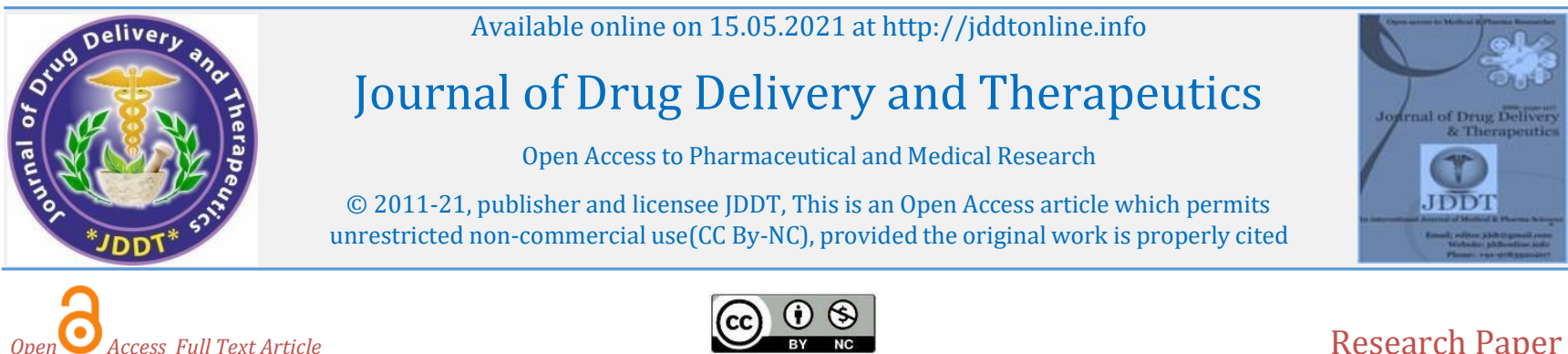

Research Paper

\title{
Academic Stress on the Incidence of Recurrent Aphthous Stomatitis: A Cross Sectional Study
}

\author{
Tedi Purnama1*, Rizki Sofian¹, Bimo Gigih Sasongko ${ }^{1}$, Muhammad Fiqih Sabilillah², Hadiyat Miko², \\ Yonan Heriyanto 3 \\ ${ }^{1}$ Department of Dental Health, Poltekkes Kemenkes Jakarta I, Jakarta, Indonesia \\ ${ }^{2}$ Department of Dental Health, Poltekkes Kemenkes Tasikmalaya, Tasikmalaya, Indonesia \\ ${ }^{3}$ Department of Dental Health, Poltekkes Kemenkes Bandung, Bandung, Indonesia
}

\begin{tabular}{ll}
\hline Article Info: & \\
\hline & Article History: \\
& Received 27 March 2021 \\
& Accepted 06 May 2021 \\
& Available online 15 May 2021
\end{tabular}

Cite this article as:

Tedi P, Rizki S, Bimo GS, Muhammad FS, Hadiyat M, Yonan H, Academic Stress on the Incidence of Aphtous Stomatitis: A Cross Sectional Study; 2021; 11(3):61-64 DOI: http://dx.doi.org/10.22270/jddt.v11i3.4854

*Address for Correspondence:
Abstract

Background: Oral and dental diseases experienced by Indonesians is recurrent apthous stomatitis with a national prevalence of $8.0 \%$. Stress can afflict children, adolescents, adults and the elderly even in a school environment, so stress can happen to anyone, anywhere. People who experience stress result in decreased concentration ability, deteriorating health, depression and sleep disorders and even dental and oral health problems, one of which is recurrent aphthous stomatitis. Objective: To determine the relationship between academic stress and the incidence of recurrent aphthous stomatitis. Methodology: this type of analytic observational study with cross sectional design. The research was conducted on students of the Department of Dental Health, Jakarta Health Polytechnic I. Collecting data using an observation sheet for the incidence of recurrent aphthous stomatitis and a questionnaire to determine the level of academic stress. Data analysis using Chi-Square. Results: it was found that academic stress on the incidence of recurrent aphthous stomatitis showed the p-value was 0.047 ( $p$ $<0.05$ ). Conclusion: There is a significant relationship between academic stress and the incidence of recurrent aphthous stomatitis

Keywords: Academic stress, recurrent aphthous stomatitis

Tedi Purnama, Department of Dental Health,

Poltekkes Kemenkes Jakarta I, Jakarta, Indonesia

\section{INTRODUCTION}

Stress is a problem that often occurs in humans. This is because stress has become a part of life that cannot be avoided. Stress can also affect anyone, children, adolescents, adults and the elderly. Stress can also occur in the school environment, work, family and also the environment around the house. In other words, stress can happen to anyone and anywhere. ${ }^{1,2}$

The incidence of stress is still high and varies widely in various groups in Indonesia. Riskesdas 2013 based on the prevalence of mental emotional disorders (psychological distress) in Indonesia in the population reached $11.6 \%$ or around 19 million of the total population nationally. The results of research by Kamso et al. stress in working groups is higher than the general population, for example in Jakarta, the incidence of stress in young executives reaches $25 \%$. Larasati's research in 2015 stated that stress in America is mostly caused by work stress. ${ }^{3-5}$

Stress is a stressful condition experienced by a person, the impact of the work environment and / or psychosocial environment that is detrimental to the. Strengthened by Nasir \& Muhith, states that stress is an unpleasant condition for humans where humans see demands in a situation as burdens or beyond their ability to meet these demands.
Stress will occur when it is caused by various demands, for example when humans face challenges, when faced with physical or mental threats, or when trying to overcome unrealistic expectations from their environment. Thus, it can be interpreted that stress is a body's defense system where there are things that interfere with self-integrity, so that it can disturb the peace which is interpreted as a demand that must be resolved.6,7

Symptoms or signs that someone experiences when they experience stress include: symptoms of stress related to physical stress symptoms related to emotional or mental symptoms of stress related to work. Even people experiencing stress will tend to show decreased concentration abilities, deteriorating health, depression and sleep; causing oral health problems, one of which is recurrent aphthous stomatitis. ${ }^{1,8}$

Based on Riskesdas 2018, it shows that dental and oral diseases that are often experienced by Indonesians, one of which is Recurrent Aphthous Stomatitis (RAS) with a national prevalence of $8.0 \%$. The prevalence of RAS in the world population varies from $5 \%$ to $66 \%$ with an average of $20 \% .{ }^{9,10}$

Recurrent aphthous stomatitis is an oral disease whose cause is not known with certainty, but there are several predisposing factors that are thought to trigger RAS. Several predisposing factors such as stress, food allergies, genetics, trauma and hormonal imbalance are thought to be the trigger for RAS. 
Recurrent aphthous stomatitis often occurs due to trauma, hormonal changes, physical or psychological stress and chemical irritation. ${ }^{11,12}$

Several studies have shown that there is an association between stress and recurrent aphthous stomatitis. According to Tangkilisan that professional education students of the Dental Education Study Program (PSPDG) of the Faculty of Medicine, Sam Ratulangi University, show that $59.7 \%$ of students with SAR experiences have high levels of stress. According to Wowor et al. proved that there was a significant relationship between stress and recurrent aphthous stomatitis in PSPDG students. According to Junhar et al. there is a relationship between stress and recurrent aphthous stomatitis in prisoners. $8,13,14$

\section{MATERIALS AND METHODS}

This research is an analytic observational study with a crosssectional approach. The research was conducted at the Department of Dental Health, Jakarta Health Polytechnic I in March 2021. The sampling technique used a total sampling of 36 respondents, namely all third-level students who are working on their final scientific paper. The independent variable in this study was academic stress and the dependent variable was the incidence of recurrent aphthous stomatitis.

Academic stress data collection is measured by a checklist of questionnaire sheets, validity and reliability tests have been carried out by the same previous researcher who examined stress. ${ }^{15}$ The incidence of recurrent aphthous stomatitis was measured by observing it by examining the oral cavity directly. The stages of the activity include: students filling out the consent informed sheet first as an agreement that they are willing to be research respondents, then doing it before carrying out oral examinations on all respondents in turn and giving an academic stress questionnaire that is filled out via google form.

Data analysis was performed using the SPSS statistical program for univariate analysis and presented in the form of a frequency distribution. After that, bivariate analysis with chi-square was carried out to measure the relationship of academic stress to the incidence of recurrent aphthous stomatitis in students.

\section{RESULT}

Table 1: Frequency distribution of respondent characteristics

\begin{tabular}{clcc}
\hline No. & \multicolumn{1}{c}{ Variable } & N & Percentage (\%) \\
\hline 1 & Age & & \\
& 20 years & 20 & 55.6 \\
& 21 years & 9 & 36.1 \\
& 22 years & 3 & 8.3 \\
& total & 36 & 100 \\
2 & Gender & & \\
& Male & 2 & 5.6 \\
& Female & 34 & 94.4 \\
& total & 36 & 100 \\
\hline
\end{tabular}

Table 1 shows that most respondents in the study were from the age of 20 years $(55.6 \%)$ with female gender, namely 34 respondents $(94,4 \%)$.

\section{Table 2: Frequency distribution level of academic stress}

\begin{tabular}{clcc}
\hline No. & $\begin{array}{c}\text { Level of } \\
\text { academic stress }\end{array}$ & N & $\begin{array}{c}\text { Percentage } \\
(\%)\end{array}$ \\
\hline 1 & Low & 17 & 47.2 \\
2 & High & 19 & 52.8 \\
\hline & Total & 36 & 100 \\
\hline
\end{tabular}

Table 2 shows that respondents with a low level of academic stress were 17 respondents (47.2\%) and as many as 19 respondents $(52.8 \%)$ with a high level of stress.

Table 3: Frequency distribution recurrent incidence of stomatitis aphthous

\begin{tabular}{clcc}
\hline No. & $\begin{array}{c}\text { Recurrent } \\
\text { stomatitis aptosa }\end{array}$ & N & $\begin{array}{c}\text { Percentage } \\
(\%)\end{array}$ \\
\hline 1 & Not & 13 & 36.1 \\
2 & Yes & 23 & 63.9 \\
\hline & Total & 36 & 100 \\
\hline
\end{tabular}

Table 3 shows that 23 respondents $(63.9 \%)$ experienced recurrent aphthous stomatitis and 13 respondents (36.1\%) did not experience recurrent aphthous stomatitis.

Table 4: Results of the chi-square analysis of academic stress on recurrent incidence of stomatitis aphthous

\begin{tabular}{|c|c|c|c|c|c|c|c|c|}
\hline \multirow{3}{*}{ Level of academic stress } & \multicolumn{4}{|c|}{ Recurrent aphthous stomatitis } & \multirow{2}{*}{\multicolumn{2}{|c|}{ Total }} & \multirow{3}{*}{$\begin{array}{c}\text { OR } \\
(95 \% \mathrm{CI})\end{array}$} & \multirow{3}{*}{ p-value } \\
\hline & \multicolumn{2}{|c|}{ Not } & \multicolumn{2}{|c|}{ Yes } & & & & \\
\hline & $\mathrm{N}$ & $\%$ & $\mathrm{~N}$ & $\%$ & $\mathrm{~N}$ & $\%$ & & \\
\hline Low & 9 & 52.9 & 8 & 47.1 & 17 & 100 & \multirow{3}{*}{$\begin{array}{c}4.219 \\
(0.982-18.11)\end{array}$} & \multirow{3}{*}{0.047} \\
\hline High & 4 & 21.1 & 15 & 78.9 & 19 & 100 & & \\
\hline Total & 13 & 36.1 & 23 & 63.9 & 36 & 100 & & \\
\hline
\end{tabular}

Table 4 the results of the chi-square analysis of academic stress on the incidence of recurrent aphthous stomatitis shows that the pvalue is $0.047(\mathrm{p}<0.05)$, which means that there is a significant relationship between academic stress and the incidence of recurrent aphthous stomatitis. 


\section{DISCUSSION}

Stress is a condition caused by a mismatch between something that is desired or expected with the expectations generated by the environment and the individual's own ability to fulfill his / her wishes which is considered to have the potential to harm, threaten and disturb the calm that the person cannot control. Symptoms or signs that someone experiences when they experience stress include: symptoms of stress related to physical stress symptoms related to emotional or mental symptoms of stress related to work. Even people experiencing stress will tend to show decreased concentration ability, deteriorating health, depression and sleep disorders and cause oral health problems, one of which is recurrent aphthous stomatitis. 1,8

The results showed that academic stress on the incidence of recurrent aphthous stomatitis showed that the p-value was 0.047 ( $p$ <0.05), meaning that there was a significant relationship between academic stress and the incidence of recurrent aphthous stomatitis. The results also showed the OR value of 4.219 , meaning that people experiencing stress have a 4-5 times chance of recurrent aphthous stomatitis compared to people who do not experience stress. This is in line with previous research by Tangkilisan which shows that $59.7 \%$ of students with SAR experience have high levels of stress. Research by Wowor et al. proved that there was a significant relationship between stress and recurrent aphthous stomatitis in PSPDG students. Research by Junhar et al. shows that there is a relationship between stress and recurrent aphthous stomatitis in prisoners. $8,13,14$

Stress is one of the predisposing factors for recurrent aphthous stomatitis. The response to stress causes suppression of $\operatorname{IgA}, \operatorname{IgG}$, and neutrophil functions. The decrease of IgA function in stress will facilitate the attachment of microorganisms to the mucosa so that microorganisms can easily invade the tissue and cause infection. Decreased IgG function facilitates pathological conditions because the decreased function of phagocytosis, toxins and viruses cannot be neutralized. The decrease in neutrophils will cause the phagocytosis function to decrease, resulting in a decrease in killing microorganisms. If that happens, the microorganisms that can cause SAR can develop rapidly. 16,17

The stress response causes the hypothalamus to release CRH and then release ACTH, ACTH stimulates the adrenal cortex to produce cortisol. Glucocorticoids including cortisol suppress immune functions such as IgA function. The function of IgA is to bind viruses and bacteria to prevent these microorganisms from adhering to the mucosal surface. IgA activates complement via an alternative pathway so that microorganisms are easily phagocytosed. The decrease in the function of IgA in stress will facilitate the attachment of microorganisms to the mucosa so that microorganisms are easy to invade the mucosa, microorganisms are also difficult in phagocytes causing easy infection. ${ }^{18,19}$

IgG is the main immunoglobulin formed on the stimulation of antigens. IgG diffuses easily into the extravascular tissue and performs antibody activity in the tissue. IgG coats microorganisms so that the particles are more easily phagocytosed, besides that IgG is also able to neutralize toxins and viruses. IgG can attach to Fc receptors on the surface of target cells and allow the ADCC process to occur. The decrease in IgG function in stress will facilitate the occurrence of pathological conditions, because the decrease in phagocytosis, toxins and viruses cannot be neutralized. Neutrophils react quickly to stimuli, can move to the area of inflammation because they are stimulated by chemotactic factors, including released by complement and activated lymphocytes. Like macrophages, the main function of neutrophils is to provide a non-specific immune response by carrying out phagocytosis and killing and getting rid of microorganisms. This function is supported and enhanced by complement or antibody. Neutrophils also have granules that contain destructive enzymes and various proteins that damage microorganisms under stress conditions, the function of Neutrophils has decreased, decreased phagocytosis, decreased in killing microorganisms. ${ }^{20-22}$

The response to stress releases glucocorticoids including cortisol, glucocorticoids including cortisol effects on the immune system, namely immunosuppression and anti-inflammatory effects. This effect involves more cellular immune response, anti-inflammatory effect, which is to suppress the accumulation of leukocyte cells in the inflamed area. Cortisol suppresses SigA, IgG and neutrophil cells, making infection easy. The large number of IL-1 mediators and metalloproteinase matrices causes RAS disease, so RAS is not only due to microorganisms, stress factors can also cause RAS. 18,23

\section{CONCLUSION}

Based on the results of the study, it can be concluded that there is a significant relationship between academic stress and the incidence of recurrent aphthous stomatitis in grade 3 students who are working on final scientific papers.

\section{ACKNOWLEDGEMENTS}

This study was done by self- funding from the authors. The authors thank to all participants and research assistants.

\section{CONFLICT OF INTEREST}

The authors declare that they have no conflict interests.

\section{ETHICAL CLEARANCE}

All participants were signed the informed consent prior to the data collection.

\section{REFERENCES}

1. Gaol NTL. Teori stres: stimulus, respons, dan transaksional. Bul Psikol. 2016;24(1):1-11.

2. Kupriyanov R, Zhdanov R. The eustress concept: problems and outlooks. World J Med Sci. 2014;11(2):179-85.

3. Riskesdas RI. Riset kesehatan dasar tahun 2013. Badan Penelitian dan Pengembangan Kesehatan Kementrian Kesehatan RI. 2013;

4. Kamso S, Purwantyastuti P, Lubis DU, Juwita R, Robbi YK, Besral B. Prevalensi dan determinan sindrom metabolik pada kelompok eksekutif di Jakarta dan Sekitarnya. Kesmas J Kesehatan Masyarakat Nasional (National Public Health Journal). 2011;6(2):85-90.

5. Larasati TA. Faktor-Faktor Sosial yang Mempengaruhi Stres Kerja. J Major. 2015;4(9):58-63.

6. Besral B, Widiantini W. Determinan Stres pada Pegawai Kementerian Kesehatan Republik Indonesia. Kesmas J Kesehatan Masyarakat Nasional (National Public Health Journal). 2015;9(3):222-8.

7. Nasir A, Muhith A. Dasar-dasar keperawatan jiwa: pengantar dan teori. Jakarta Salemba Med. 2011;

8. Tangkilisan V. Gambaran Stres Pada Mahasiswa Pendidikan Profesi Program Studi Kedokteran Gigi Fakultas Kedokteran Universitas Sam Ratulangi Yang Memiliki Pengalaman Stomatitis Aftosa Rekuren. eGiGi. 2013;1(2).

9. Riskedas RI. Hasil utama riskesdas 2018. Jakarta Kemenkes RI. 2018;

10. Neville BW, Damm DD, Allen CM, Chi AC. Oral and maxillofacial pathology. Elsevier Health Sciences; 2015.

11. Darmanta AY. Angka kejadian lesi yang diduga sebagai stomatitis aftosa rekuren pada mahasiwa program studi kedokteran gigi fakultas kedokteran universitas sam ratulangi. e-GiGi. 2013;1(2).

12. Yuniarsih N, Muchtaridi M, Wathoni N. Hydrogel untuk reccurent aphthous stomatitis. Farmaka. 2018;16(2):10-21.

13. Wowor YP, Munayang H, Supit A. Hubungan Stres dengan Stomatitis Aftosa Rekuren pada Mahasiswa Program Studi Pendidikan Dokter CODEN (USA): IDDTAO 
Gigi Universitas Sam Ratulangi. e-GiGi. 2019;7(2).

14. Junhar MG, Suling PL, Supit ASR. Gambaran stomatitis aftosa rekuren dan stres pada narapidana di Lembaga Pemasyarakatan Kelas II B Bitung. e-GiGi. 2014;3(1).

15. Azahra JS. Hubungan antara stres akademik dengan coping stress pada mahasiswa yang sedang mengerjakan skripsi di Fakultas pendidikan psikologi. Universitas Negeri Jakarta. 2018;

16. Sulistiani A, Hernawati S. Prevalensi dan Distribusi Penderita Stomatitis Aftosa Rekuren (SAR) di Klinik Penyakit Mulut RSGM FKG Universitas Jember pada Tahun 2014 (Prevalence and Distribution of Patients Recurrent Aphthous Stomatitis (RAS) in Oral Medicine Departement of Dental. Pustaka Kesehat. 2017;5(1):169-76.

17. Sari RK, Ernawati DS, Soebadi B. Recurrent aphthous stomatitis related to psychological stress, food allergy and gerd. ODONTO Dent J. 2019;6(1):45-51.

18. Hernawati S. Mekanisme selular dan molekular stres terhadap terjadinya rekuren aptosa stomatitis. J PDGI. 2014;63(1):36-40.

19. Kumar A, Ananthakrishnan V, Goturu J. Etiology and pathophysiology of recurrent aphthous stomatitis: A review. Int J Curr Res Rev. 2014;6(10):16.

20. Preeti L, Magesh KT, Rajkumar K, Karthik R. Recurrent aphthous stomatitis. J oral Maxillofac Pathol JOMFP. 2011;15(3):252.

21. Rathee M, Bhoria M, Boora P. Recurrent aphthous stomatitis: an overview. Int J Fam Pr. 2014;13:1-6.

22. Belenguer-Guallar I, Jiménez-Soriano Y, Claramunt-Lozano A. Treatment of recurrent aphthous stomatitis. A literature review. J Clin Exp Dent. 2014;6(2):e168.

23. Slebioda Z, Szponar E, Kowalska A. Recurrent aphthous stomatitis: genetic aspects of etiology. Adv Dermatology Allergol Dermatologii I Alergol. 2013;30(2):96. 